\title{
Birth, Death and Reincarnation in the Life of a Fifteenth-Century Tibetan Princess
}

\author{
Hildegard Diemberger
}

\section{1 \\ Introduction ${ }^{1}$}

Like early modern Europe, the Tibetan Buddhist world was historically shaped by a multitude of religious experiences - most of which went unrecorded. Temples and monasteries, manuscripts and prints, as well as beautiful figurative art are the tangible vestiges of a world in which Buddhism provided the dominant framework to think about human life and the world. The focus of these endeavours lay ultimately in the achievement of universal liberation from Samsara, the cycle of rebirths and the suffering of existence, as well as in more mundane and short-term objectives: guaranteeing long life and prosperity, contributing to a good reincarnation for a deceased relative, obtaining protection against illness and misfortunes.

Most of the day-to-day devotional practices only made it into recorded narratives and images as marginal details within works that were dedicated to Buddhist deities, rulers and spiritual masters - with biographical literature providing a particularly popular genre in this respect. Tibetan biographies (Tib. rnam thar) show many parallels with medieval European hagiographies in that they provide narratives of exemplary lives, where 'memorabilia' and 'mirabilia' merge in ways that are highly effective but difficult to disentangle. ${ }^{2}$ Relying on the life of the Buddha as a paradigm, they focus invariably on the life of someone who abandoned worldly existence either as a monk/nun or as an ascetic. Structured according to predictable patterns and interspersed with well-known narrative tropes, the narrative can nevertheless be rich in detail that makes the story credible and usually straddles the lay and the monastic worlds. Life stories, often produced in hindsight by assembling notes and oral accounts of direct witnesses, were told according to literary models that

1 This article is based on research carried out in the framework of two projects supported by the Arts and Humanities Research Council UK (RG42232; RG 55631).

2 See Tambiah S.J., The Buddhist Saints of the Forest and the Cult of Amulets: A Study in Charisma, Hagiography, Sectarianism, and Millennial Buddhism (Cambridge: 1984).

(C) HILDEGARD DIEMBERGER, 2019 | DOI:10.1163/9789004375888_018

This is an open access chapter distributed under the terms of the prevailing CC-BY-NC-ND License at the time of publication. 
privileged the soteriological endeavour over any other concern (these could highlight monastic and scholarly achievement or transgressive life experiences according to the tradition of the 'mad' ascetic). Since lives were also lived and understood by the subject according to earlier exemplary referents it is often difficult to disentangle the layers that led to the creation of a rnam thar. It is the less glamorous, less predictable and more contingent detail that is often the richest source of historical insight. Especially biographies written close to the events can provide a glimpse of real life experiences and wider social and cultural contexts (particularly if read against the grain and with reference to other sources). As in early modern Europe, religion and politics in Tibet were dominated by men, notwithstanding the examples of some women (usually belonging to the royalty or the aristocracy) who played crucial roles in a variety of contexts. It is therefore not surprising that most of the available biographies are dedicated to male spiritual masters and that those that focus on female ones are few and far between. Recent research, however, has brought to light some important works that reveal the lives of extraordinary women from different historical periods ${ }^{3}$ and in some cases provide information about their networks which included many more ordinary women of their time. ${ }^{4}$ In most cases accounts of ordinary and extraordinary domestic devotions are an important prelude to the spiritual choices that led to a woman's abandonment of worldly life. It is precisely the richness in ordinary detail that grounds the narrative in recognizable human experience and anchors it to specific places and times.

The biography of Chokyi Dronma (1422-1455) is a fifteenth-century account of a Tibetan princess who abandoned royal life to become a nun, was eventually recognized as the emanation of a female deity and established a female reincarnation line that has lasted up to the present day [Fig 16.1]. From this narrative she emerges as a great patron of printing and manuscript production, Buddhist art and engineering work for the benefit of all living beings, recalling in many ways some of the great European Renaissance women. Some of the passages of this biography, especially those that concern her early life as a princess, married to a neighbouring ruler according to the political strategies

3 See for example Schaeffer K., Himalayan Hermitess: The Life of a Tibetan Buddhist Nun (Oxford - New York: 2004); Diemberger H., When a Woman Becomes a Religious Dynasty: The Samding Dorje Phagmo of Tibet (New York: 2007); Jacoby S., Love and Liberation: Autobiographical Writings of the Tibetan Buddhist Visionary Sera Khandro (New York: 2014).

4 For example I identified a wide range of women within networks that supported the production of Tibetan print editions in the fifteenth century. Diemberger H., "Tibetan Women as Patrons of Printing and Innovation", in Diemberger H. - Ehrhard F.-K. - Kornicki P. (eds.), Tibetan Printing: Comparisons, Continuities and Change (Leiden: 2016) 267-308. 


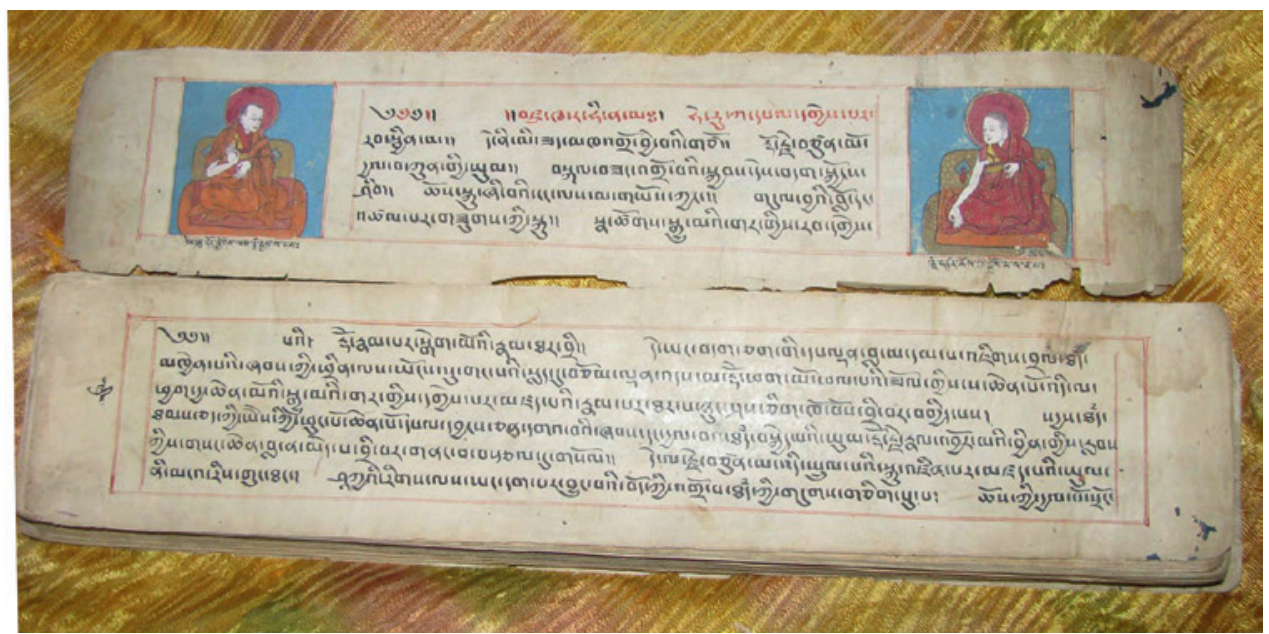

FIGURE 16.1 Manuscript of the biography of Chokyi Dronma (15th century). Ye shes $m k h a^{\prime}$ 'gro bsod nams 'dren gyi sku skyes gsum pa rje btsun ma chos kyi sgron ma'i rnam thar. 144 folios. Incomplete manuscript PHOTO TAKEN BY PASANG WANGDU

of her father, give insight into the world in which she lived and eventually fought her battle to pursue her spiritual aspirations. In this paper I focus on these passages as they cast light on Chokyi Dronma's worldly experiences and on the way in which lay devotion provided the basis for the more radical spiritual pathway that she chose to follow later in her life. As a child of an unlucky queen, who produced only daughters and had to endure the competition of a junior royal consort mother of the male heir to the throne, Chokyi Dronma sought refuge in spirituality to negotiate a difficult position in a world of political marriages and dynastic disputes. This was the world she sought to abandon but with which she engaged throughout her life: as a pawn first, as an idiosyncratic religious leader later [Fig. 16.2].

\section{The Biography of Chokyi Dronma Within Tibetan Biographical Tradition}

The manuscript of the biography of Chokyi Dronma is a unique source, the original of which is currently preserved in the Tibet Museum of Lhasa. ${ }^{5}$ It is incomplete and therefore its dating and authorship had to be reconstructed

5 This manuscript (Tibet Museum nr. 4281) was deposited there after having been kept at the Palace of Nationalities in Beijing where it had arrived from the library of Drepung monastery 


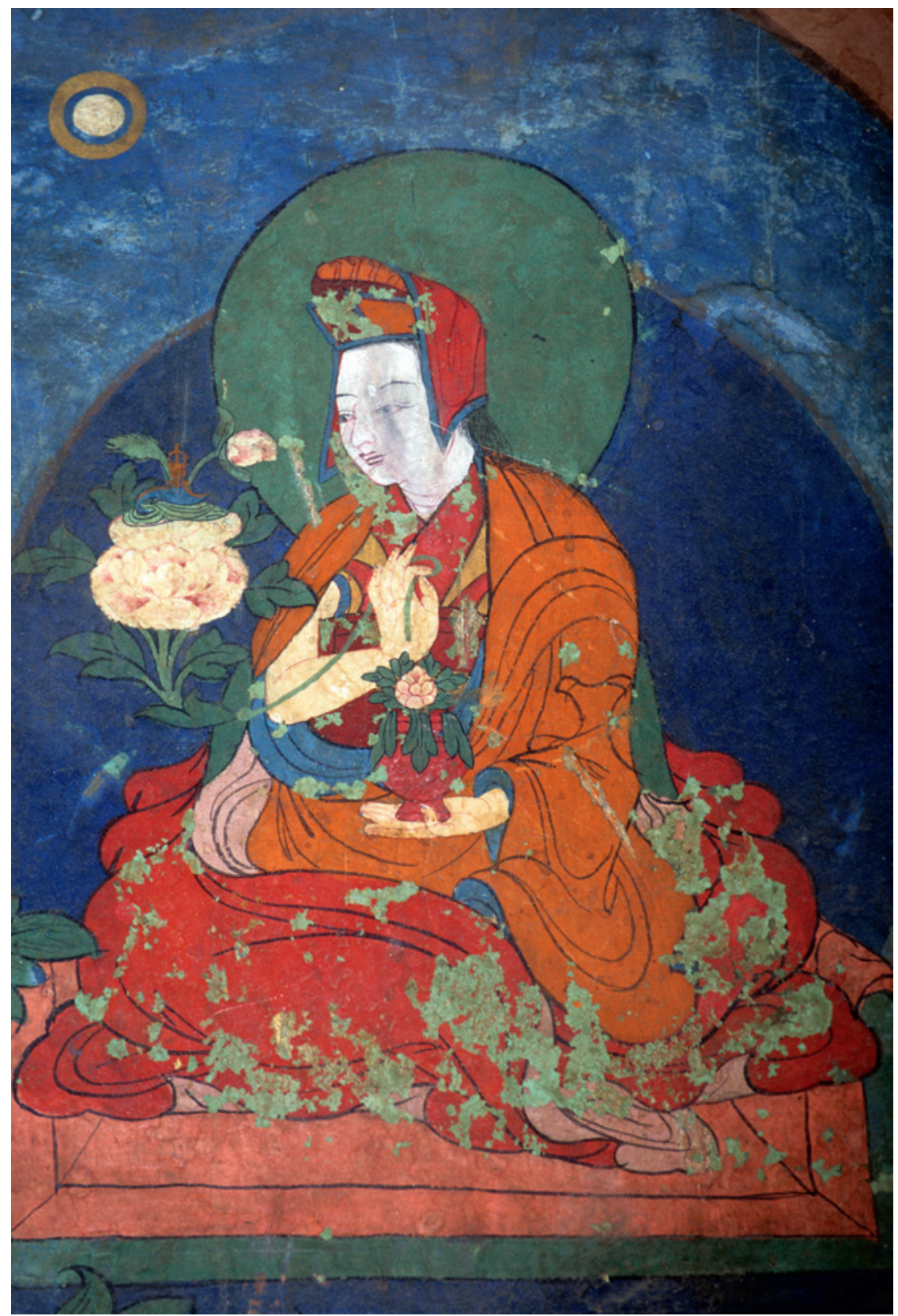

FIGURE 16.2 Chokyi Dronma in a mural painting at Nyemo Chekar monastery

(Central Tibet)

PHOTO TAKEN BY THE AUTHOR 
on the basis of internal evidence and other sources such as the Bo dong chos 'byung (The History of Bodong) and the Biography of Thangtong Gyalpo. ${ }^{6}$ It was written by a male disciple of the princess, who was born in the same region and followed her during her peripatetic life until her final journey to the holy site of Tsari in south-eastern Tibet, where she died aged 33. Predictable Tibetan Buddhist tropes clearly inform the narrative; however, there is much detail that reflects the biographer's first-hand experience of the events and his familiarity with people and places. From this point of view it is quite an exceptional work, as Tibetan biographies tend to be rather formulaic. It is also the oldest known Tibetan biography of a female spiritual master and became fairly influential before being intentionally or unintentionally withdrawn from circulation (presumably in the seventeenth century) and eventually being deposited in Drepung Monastery in Lhasa.

Glimpses into the Domestic Life of a Fifteenth-Century Princess

Chokyi Dronma was born in 1422 as the first child of the Tibetan king Thri Lhawang Gyaltshen (1404-1464) and queen Dode Gyalmo, who ruled over the region of Mangyul Gungthang in south-western Tibet. ${ }^{7}$ At that time Tibet was nominally under the loose rule of the Rinpungpa but was basically fragmented in a multitude of regional powers, involved in conflicts and alliances that were often supported by marriage alliances among the local elites. At the time of Chokyi Dronma's birth the kingdom of Mangyul Gungtang desperately needed an heir. The fact that she was a girl and that her next sibling was also a girl,

in Lhasa. So far it is unpublished, there are a few photocopies in circulation and it is going to be made available in a trilingual book edition (Tibetan, English, Chinese), which I am preparing with Tibetan colleagues. I was kindly given a photocopy by Leonard Van der Kuijp, Head of Sanskrit and Tibetan Studies at Harvard University, when I published an English translation in the monograph Diemberger, When a Woman Becomes a Religious Dynasty.

6 The biography of Thangtong Gyalpo is a life narrative of one of the masters with whom Chokyi Dronma interacted and was written in 1607 on the basis of pre-existing sources, including a version of the biography of Chokyi Dronma. The Bo dong Chos 'byung is a history of the religious tradition to which Chokyi Dronma belonged and was written in the early seventeenth century. Both sources offer important information on what happened at the very end of Chokyi Dronma's life and the people who were closest to her. For a full discussion of the final part of Chokyi Dronma's life as well as the dating and authorship of her biography, see Diemberger, When a Woman Becomes a Religious Dynasty.

7 For a detailed discussion of the history of this region, see Everding K.H., Das Königreich Mang yul Gung thang, vols. 1 and 2 (Bonn: 200o). It was located on the Tibetan plateau north of Kathmandu and included the oldest and most important traditional trade route that connected Kathmandu to Lhasa. 
may have had an impact on the way she was treated in her early childhood as female rulers were rare but not unheard of in the history of her kingdom (this situation would change radically with the birth of her brother, see below).

Predictably the biography describes the young girl as very precocious in her dedication to spiritual aspirations. According to her biography Chokyi Dronma learnt to read and write from her mother:

At the age of four she started to be taught how to read by her mother by looking at a model of letters ( $k a$ dpe). As she started to read the first letter $k a$, she was able to continue reading the kha ga spontaneously without any instruction. She thus became able to read and write perfectly.

Biography of Chokyi Dronma, fol. $5^{\mathrm{V}}$

The description of the way in which she learnt the Tibetan alphabet is an interesting detail as it is relatively specific and plausible in its practicality, and seems to point to the fact that some women (at least those belonging to the higher levels of society) were literate. Chokyi Dronma's own commitment to the spread of literacy, especially among women, is reflected in a later passage in her biography, which highlights the fact that she taught nuns to read. This is also corroborated by her dedication to supporting the editing and printing of texts. ${ }^{8}$

Access to scriptures marked her religious life in multiple ways. They provided not only the basis for the rituals that she used to recite as daily practice when she was still leading a secular life (the biography describes them in some detail); they also provided a source of inspiration for some of her decisions. For example, the biography states that reading the Lalitavistara, which tells the story of the Buddha, influenced her decision to abandon worldly existence.

\section{Domestic Devotions and Marriage Politics}

The biography often reveals the tensions that Chokyi Dronma experienced throughout her life: she had to choose between fulfilling the mundane expectations of being a good princess and the spiritual aspirations that drew her towards abandoning worldly existence. A telling passage refers to the moment in which her mother came to know that the king had taken another queen and produced the expected male heir to the throne:

8 See Diemberger, “Tibetan Women as Patrons of Printing and Innovation" 267-308. 
While [Chokyi Dronma] was staying at Gonpashag, ${ }^{9}$ a junior wife of the king, one of the sisters from Bongdzog, ${ }^{10}$ gave birth to a son, [her brother] Canneba [alias Thri Namgyal De], fulfilling local aspirations. Reacting to her anxiety of having had only two daughters, [Chokyi Dronma's mother] spoke bitterly to the Venerable [Chokyi Dronma] and her sister calling them 'two female misfortunes'. The precious Lady of Prosperity [Chokyi Dronma] said: "Mother! Please come here! Let us make a plan for all of us; mother and daughters". Her mother was surprised and asked: "Please tell me what you think?" She told her mother: "Although since I was a little girl I have wished to become a renunciate, in the first part of my life I will become a married woman because of the karma accumulated previously $[\ldots]$. Anyway in the first part of my life I will lead a secular life fulfilling your expectations, as my mother. In the later part of my life I will take the vows and will fulfil my hope regarding my future existence. But, please, do not call us 'misfortunes', I am an excellent one!" The mother was greatly surprised and pleased with this, and faith was spontaneously awakened in her.

Biography of Chokyi Dronma, fols. $7 \mathrm{v}-8 \mathrm{r}$

Chokyi Dronma's destiny of being sent as a bride to a neighbouring kingdom became real when her father received a marriage proposal from the ruler of southern Lato [Fig. 16.3], a kingdom immediately to the East of Mangyul Gungthang:

The king received a request [for his daughter] to marry Tshewang Tashi, the son of Situ Lhatsen Kyab, the ruler of Southern Lato. ${ }^{11}$ Her father accepted this request thinking that this would benefit everyone and ordered the venerable lady [that she should go to Southern Lato as a bride]. [When she heard this] she said to her father: "I do not want to contradict my father's order this time. However, having now accepted to go for the sake of the living beings, later, when the right time comes, should not

9 This is a reference to a place south of the capital where Chokyi Dronma spent some of her childhood with her mother.

10 The name Bongdzog is both a place and a clan name referring to people inhabiting the Rasuwa Valley in Nepal. This points to a marriage alliance between Chokyi Dronma's father and the neighbouring polity to the south (see Diemberger, "Tibetan Women as Patrons of Printing and Innovation" 295).

11 Situ Lhatsen Kyab was a ruler of southern Lato, the region immediately north of Mt Everest, in the fifteenth century. His father Situ Chokyi Rinchen (died 1402) established the capital in Shekar and was celebrated in the local history Shel dkar chos byung. See Wangdu P. - Diemberger H., Shel dkar chos 'byung, History of the White Crystal (Vienna: 1996). 


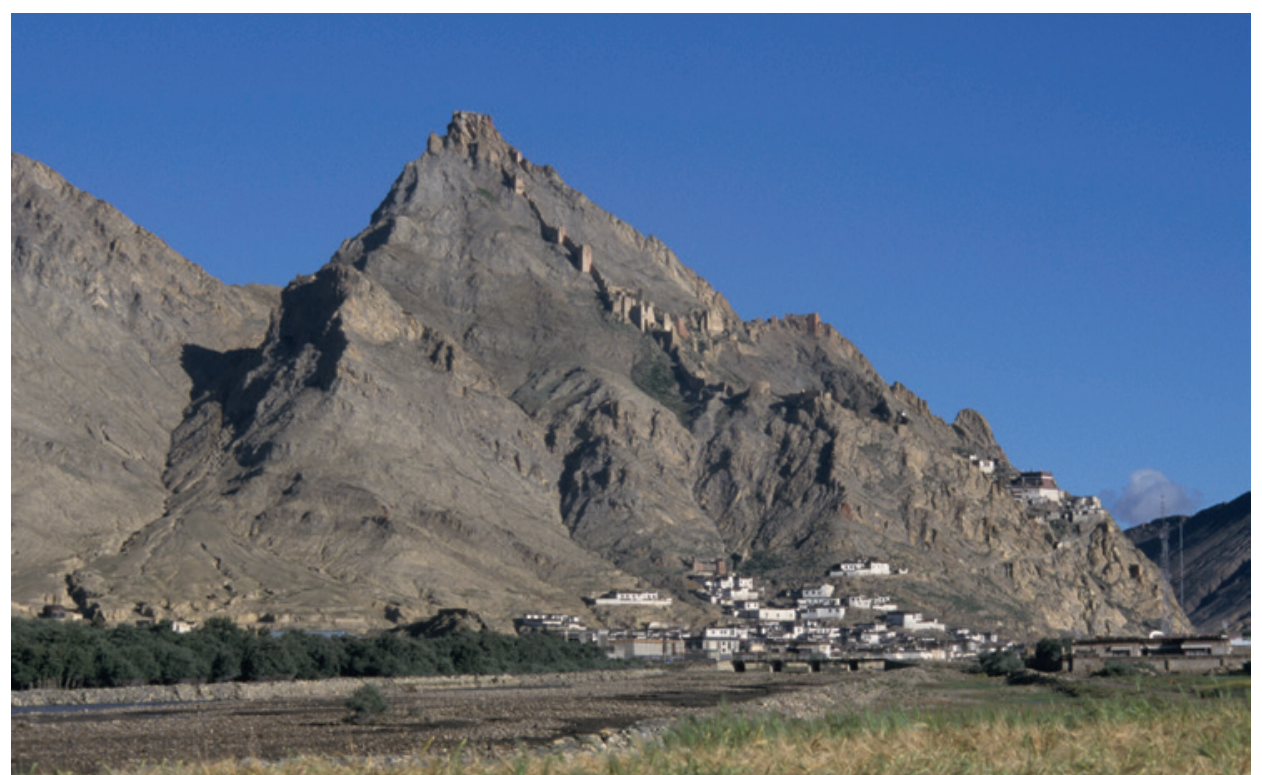

FIGURE 16.3 Ruins of the Shekar fortress where Chokyi Dronma lived for a few years as the daughter-in-law of the local ruler before becoming a nun PHOTO TAKEN BY THE AUTHOR

I take the monastic vows?" Laying her hand on the statue of Gurkyi Gonpo (Panjaranath) ${ }^{12}$ [and thus calling on him as a witness] she took an oath to this effect.

Biography of Chokyi Dronma, fols. 10v-11r

When the time of the marriage came she behaved like a Tibetan bride; during the ceremony she received gifts and shed tears before departing for her new home. The biography describes the event in great detail, combining extraordinary epithets and descriptions with much more ordinary features of Tibetan marriage rituals as they are still practised in Tibetan areas today. According to the narrative (which was clearly written in hindsight) the princess as a daughter-in-law was trying to comply with the required protocol whilst anticipating the fact that she was going to abandon worldly life at a later stage:

[Chokyi Dronma], thought: "I came here with two tasks: one of this world and one beyond the world. For the sake of my ancestors I have avoided sins and accomplished virtuous deeds. In particular, I have paid respect 
and provided service to the Buddha's doctrine. I have taken good care of our subjects and servants. However, I cannot stay long in this family. If I were to stay, I would be committed to showing respect to my parents-inlaw and in particular to my master of the house [i.e. husband] as if they were gods and provide them with good service forever. Therefore, when the appropriate moment comes I will enter the door of the precious doctrine and practice Buddha's teachings in the most appropriate way.

Biography of Chokyi Dronma, fols. $18 \mathrm{v}-19 \mathrm{r}$

The biography also highlights that whilst leading the worldly life of a Tibetan royal daughter-in-law she was already practising a lot of domestic devotions that echoed those practised in monasteries:

At Shekar she kept practising her daily and nightly routine: after waking up she would meditate on the entire Stages of the Path to Enlightenment (Lam rim), then she would recite her confession (Byang chub rtung bshags) one time. Then, from getting up until the Ritual for complete spiritual liberation (Cho ga rnam grol), she would wash to refresh her body and perform spiritual purification (gso sbyong). She also used to perform the Realisation of all gods (Lha du ma'i mngon par rtogs pa). She would then celebrate the Stages of the White Torma Offering (dKar gtor gyi rim $p a$ ), the Praise of the Buddha referring to his twelve deeds (bsTon pa'i bstod pa mdzad pa bcu gnyis), the praise King of the Dharma (bsTod pa chos kyi rgyal po) by the venerable Sakya Pandita and the Ritual offering to Tara (sGrol mchod). At that time, before getting the teachings from the Omniscient [Bodong Chogle Namgyal, who would become her main spiritual master], she used to rely mainly on the texts by the great Sakyapa, spiritual father and son [i.e. Sakya Pandita and Phagpa]. ${ }^{13}$

Biography of Chokyi Dronma, fols. 19v-2or

Portrayed as a champion of Buddhism, she reportedly took every opportunity to promote it in a setting in which pre-Buddhist practices were still favoured by some people, including her husband. The description of her daily routine is a blend of ordinary and extraordinary detail, revealing the fact that she was at the same time a regular royal daughter-in-law and an extraordinary spiritual woman:

13 Sakya Pandita Kunga Gyaltsen (1182-1251) and Phagpa (1235-1280) were famous spiritual masters of the Sakya tradition, which was widely practised in the region. 
After breakfast, at the time of the regular [lunch] snack, following the wish of her husband she would play migmang ${ }^{14}$ putting garlands of jewels as bets. Initially she agreed to this many times; later she asked to stop playing migmang but her husband insisted a few times. She then said: "In this case, what is the point of making such ordinary bets? Like in the case of Sakya Pandita's debate with the heretics (mu stegs) ${ }^{15}$ let us put Buddha's religion and Shenrab's religion [i.e. Bonpo religion] as the bet in a game of migmang". Because of the power of karma, what was in her mind did not happen. She was just told "We can play later". After dinner she enjoyed talking to some spiritual masters and some new people who had arrived to meet her. She would comment on what they were saying and in doing so she used to impress and delight them. Before performing ritual offerings of chang and tea, she would read the songs and poems of former lamas to avert the demons. She also used to perform some of the [above mentioned] rituals again. She used to go to bed at a regular time. When she was together with other people, her way of behaving and speaking was always extraordinary. Therefore common people used to gossip, saying that they felt as though they were in a monastery. With her behaviour she used to eclipse the others. However, the people close to the great lady, such as her father- and mother-in-law, her husband and their retinue, considered her behaviour as that of a new bride. She had a very clear understanding of the rights and wrongs of any action and behaved far beyond anyone's expectations so that nobody would challenge her.

Biography of Chokyi Dronma, fols. 2or-v

The biography also highlights that in addition to her daily practices in the domestic environment, she was trying to participate in the activities that were taking place in the main monastery. However, as a laywoman she was able to do so only from the margins:

During the summer and winter celebrations she did not join the centre of the gathering ${ }^{16}$ to avoid interfering, she just used to reach the door of the garden (kun dga' ra ba) where these were performed. She then used to pray for the monastic community and prostrate herself before them.

Biography of Chokyi Dronma, fol. $20 \mathrm{v}$

\footnotetext{
14 Migmang (mig mangs) is a Tibetan table game, which is reminiscent of chess and similar games.

15 This is a reference to a famous debate that took place in Mangyul Kyirong in which Sakya Pandita defeated a Saivaite master and thereby defended Buddhism.

16 Dbyar chos dgun chos were the most important religious events in the ritual calendar of the Shekar monastery, see Shel dkar chos 'byung, fol. $42 v$.
} 
The lifestyle described in the biography is of course highly hagiographic. However, the precision and the detail of the daily routine suggests that she was probably actually leading a very devout life in which ritual activities marked the pace of life. The recitation of prayer, the reading of scriptures and purification practices were central to these activities and present many parallels with popular Christian devotion. Food, in terms of offerings as well as fasting practices, was (and still is) important in popular Buddhist religiosity, as it used to be for medieval European women. ${ }^{17}$ Chokyi Dronma later in her life became a master of ritual practices (bcud len) that enabled her to draw sustenance from the environment without needing food. Her highly spiritual attitude to life provided her with a source of strength when negotiating her position of daughterin-law in the new setting. It is within this very religious framework that she experienced some of the key events in the life of a young woman, including childbirth.

The biography states that at the age of eighteen, i.e. in 1440, Chokyi Dronma became pregnant. At that time she was very well looked after:

When she was nineteen [i.e. eighteen according to western reckoning] she became pregnant. The Great Situ, the queen and the prince took very good care of her, treating her like the apple of their eyes. They had religious services performed regularly for her and had the whole retinue thinking only about her. When the time for the delivery came, as the sun was rising, she gave birth, without any harm, to a perfect daughter. Tsencham [the mother-in-law] came and asked: "Did you have a good delivery? Did you suffer any pain?” The glorious woman [i.e. Chokyi Dronma] answered: "The birth was easy and I did not face any hardship; the baby is a girl." Tsencham said: "The most important thing is that your body is in good condition. There is no difference between boy and girl. The marriage relation with the Changpa [i.e. the rulers of the neighbouring kingdom to the north $]^{18}$ is continuing. Later you will give birth to one child after the other." She spoke in this way to please her.

\footnotetext{
17 See Bynum C., Holy Fasts and Holy Feasts: The Religious Significance of Food to Medieval Women (Berkeley - London: 1992).

18 The family of the rulers of Northern Lato to which Tsencham belonged. This is a reference to the fact that the ruling families of Northern and Southern Lato had regular marriage alliances and the birth of a daughter was precious for this.
} 
Despite the hagiographical framework, the narrative is candid in reporting that the words of the mother-in-law were spoken to please Chokyi Dronma, countering the predictable disappointment with the gender of the child with observations about the good physical condition of the princess and commenting on the fact that daughters were an asset in marriage alliances. After her mother-in-law Chokyi Dronma was visited by her husband, with whom she had a difficult relationship:

Then Tshewang Tashi came to see her. Tsencham went into a small inner room [and left them alone]. The master of her house [i.e. her husband] asked several times: “Did you face any hardship?" The [princess'] emanation body rejoicing in the dance of illusion answered: "I did not encounter any suffering. This time, even if there had been some suffering, I could have endured it easily. However, I cannot stand the suffering of being caught in Samsara. The pleasure of emotional attachment is very short; it does not bring any long-term benefit. Permanent happiness should be aimed for." Tshewang Tashi was speechless. Later he suggested that Yungdrung Lingpa, a great Bonpo master, should become the child's teacher. The Lady of Prosperity replied: "Had this child been a boy, you would have had the power to decide. The child being a girl, according to dowry agreements (nor la 'dum 'dug pas), ${ }^{19}$ she will take refuge in the Jewel of Buddhism." The parents took affectionate care of their newborn child. Nannies provided food, milk and play. The monks of Gyade monastery performed religious services and court attendants further fostered her growth in another auspicious room.

Biography of Chokyi Dronma, fols. 26r-27r

This passage reveals a tension around the control over the religious upbringing of the daughter, suggesting that the husband would have preferred her to follow the Bonpo religion to which he was committed. However, Chokyi Dronma claimed the right to make the decision in relation to her female offspring, revealing elements of bilineality in the kinship system. The disputes around different religious affiliations among members of the same ruling family betray a rather complex and divided setting even if Buddhism was already clearly dominant. According to the biography the baby princess was well looked after. She belonged to the elite and was an asset in marriage alliances. However, a

19 This is a reference to marriage arrangements and the transmission of certain goods and rights in the female line. 
different passage betrays the fact that infanticide of baby girls was not unheard of and this was an extreme manifestation of a wider set of attitudes towards women that Chokyi Dronma consciously opposed after becoming a highly influential nun:

When the Female Buddha Woman of Wisdom [i.e. Chokyi Dronma], was about to arrive at Shekar from the palace of her father as a bride, the mother of a dumb boy gave birth to four daughters at once, in a locality in the southern region. The father was furious about this and tried to throw the girls into the water. However, the dumb boy all of a sudden spoke: "They cannot be thrown away! The four girls are four dakinis. The head of the dakinis, Konchog Gyalmo [i.e. Chokyi Dronma] is about to come here from Ngari!" Later these girls became extraordinary beings as it was predicted.

Biography of Chokyi Dronma, fols. 33v-34r

Not long after the birth of her daughter, Chokyi Dronma went to the hot springs where she fell gravely ill and almost died. When she came back she did not seem to want to look after her daughter. A rather obscure passage states that when she came back:

She saw her child but hardly did anything to provide for her. Tsencham Gyalmo was extremely upset about this and said to [her husband] the Great Situ: "She has not been looking after her child! Even wolves or hawks care for their offspring." When Vajrayogini [Chokyi Dronma] heard what her mother-in-law had said she commented: "Royal offspring have an innate nature. A good mother is also necessary and up to now I have done all that I could do to look after this child. However, from now on it is not necessary for me to do so. It is not worth yearning for the sources of suffering." Her irritated mother-in-law said: "She might be a Buddhist. However, her behaviour seems very worldly. When she is hurt by something, even if her mind is affected just a little, she never forgives and she will take revenge ruthlessly. She is a cold-hearted person indeed. Who is like that? It is difficult to assess her." The Great Situ smiled and said: "Who dares to assess her? Currently nobody is superior to Konchog Gyalmo in Central Tibet. Where is someone similar? Where else is such a daughter-in-law?"

Biography of Chokyi Dronma, fols. 29r-3or 
The narrative of Chokyi Dronma's detachment from her daughter may be inspired by the story of the Buddha who abandoned his wife and child to pursue enlightenment; this resonance is also highlighted by the author's choice of mentioning her as Vajrayogini, the epithet of a Buddhist female deity. ${ }^{20}$ However, this episode may also betray a range of other tensions around her motherhood, and the reported dialogues in which she is mentioned with her secular name, Konchog Gyalmo, are rather obscure and read like fragments of dialogues that took place in a conflictual situation. Not long afterwards she left for her homeland to mediate a conflict between her father and her brother who often clashed because of the ambition and rough character of the young prince and because of the fact that they were supported by different constituencies in their kingdoms. At that time Chokyi Dronma left her daughter behind, in the care of her in-laws and the court.

The biography describes how on her way back from her visit to her homeland where she mediated the conflict successfully, she felt that things were not quite right at Shekar:

While traveling towards the capital, she became increasingly anxious that her daughter might not be there any longer [and that she may have died] while she was in Ngari [i.e. Mangyul Gungthang, her homeland]. At first Tsencham and the prince did not have the courage to tell her [the sad news] and thus the Great Situ himself sent a letter: "You came here fruitfully, but we were not as fruitful as you were. As nothing else could be done, we tried to earn merits by carrying out her funeral in the best possible way." The Great Yogini thought that her daughter had died because her husband had requested some Bonpo priests to take care of her and wrote a reply saying: "It is the fate of any being that was born to die. There is no point in worrying about this. However, the child should really have lived longer, but because of the actions against Buddhism this did not happen. Now there is no point in worrying, this child will find her own way." The Great Situ was glad and relieved at this reply and showed it to

20 For a detailed discussion of this deity, see English E., Vajrayoginī: Her Visualizations, Rituals and Forms (Boston: 2002). 
everybody. The people of his court said: "Perhaps this time [Konchog] Gyalmo [i.e. Chokyi Dronma] has some regret for how things have gone. Later she may be blessed by the birth of another child; this Lady Source of Prosperity will achieve a successful birth for the ruler and his son."

Biography of Chokyi Dronma, fols. $3^{1 \mathrm{v}-32 \mathrm{r}}$

Certainly the religious framework provided Chokyi Dronma with a way of coping with the loss of her child. Trying to see through the hagiographical narrative, a reader can perceive a sort of blame game that must have surrounded the premature death of the baby princess. This is also highlighted by the fact that the reported passages of direct speech refer to Chokyi Dronma with her secular name, Konchog Gyalmo - the name that would have been commonly used for her at the time. Was it Chokyi Dronma who did not care properly for her daughter and left for her homeland? Or was it the paternal family of the child that did not look after the baby as they should have? How much regret surrounded the event? The reference to the child's reincarnation and the anticipation that the princess would give birth to more children were both common ways of putting things to rest (as I have often seen happening now among Tibetan rural communities).

No children would follow, though. Not long after the death of her daughter, Chokyi Dronma decided to give up secular life for good and embrace the spiritual pathway of a nun. Did the death of her daughter play a part in this? The biography emphasizes the fact that Chokyi Dronma had already made up her mind from an early age and that she would dedicate herself completely to a spiritual life as soon as this would become possible. However, many of the descriptions of life events seem to betray a much more contingent nature of her trajectory and the likelihood that the narrative was describing things in hindsight, projecting later views onto her past.

The struggle to leave worldly life and become a nun was far from easy. Chokyi Dronma had to assert herself against both her family of origin and the family she had married into. ${ }^{21}$ Despite it being suggested that she should fulfil her

21 This is a recurring feature in the life of Buddhist female spiritual masters and has many parallels in Christian hagiographical tradition: see for example Saint Clare of Assisi; see Bartoli M., Saint Clare: Beyond the Legend (Los Angeles: 2010) and, for later examples, see Davis N.Z., Women on the Margins: Three Seventeenth-Century Lives (Cambridge, Mass.: 1997). Like Clare of Assisi, Chokyi Dronma became a referent for later women who followed her example of withdrawal from worldly life and fulfilment through support of 
spiritual aspirations by acting as a patron of Buddhist deeds (an easier and less controversial route), she did not accept compromises. The biography gives a detailed description of her lengthy struggle, which was the source of a lot of anxiety for the people around her and even a war between the two neighbouring kingdoms. This includes powerful descriptions of scenes in which hair, as a well-known Buddhist personal symbol ${ }^{22}$ with many resonances in the Christian context, plays an important part: she challenges her family by publicly tearing her hair out and offers her hair in the monastic initiation ceremony.

Eventually she left her royal residence and reached Bodong Chogle Namgyal, her spiritual master, in the Porong Pemo Choding monastery where she became a novice and after a while a fully ordained nun. She became one of the very rare instances of a Tibetan woman having obtained full ordination, something which is currently a hotly debated topic in Buddhist circles. ${ }^{23}$ Later in her life Chokyi Dronma was recognized as the emanation of the Buddhist deity Vajravarahi (a form of the female Buddhist deity Vajrayogini), establishing a female reincarnation line that lasts up to the present day. Her twelfth reembodiment is currently the head of Samding monastery in Southern Tibet.

\section{8} Conclusion

The biography of Chokyi Dronma offers a rare glimpse into the life of a princess in fifteenth-century Tibet. Her case, like that of other less prominent female Buddhist practitioners, suggests that religion could play an important part in a woman's life despite the scanty documentation that attests to this. Domestic devotions were among the lay religious practices that offered a powerful framework within which a woman could deal with the wide range of challenges that shaped her life as daughter, daughter-in-law, mother and grandmother. At the same time the link between lay devotion and monastic life offered, through the practice of patronage, a socially sanctioned way for women to be actively involved in wider spiritual endeavours. ${ }^{24}$ The latter also offered

spiritual deeds; see Diemberger, "Women and Patrons of Printing and Innovation" $267-308$.

22 See Obeyesekere G., Medusa's Hair (Chicago: 1981) for a compelling discussion of hair as personal symbols in Buddhism.

23 Mohr T. - Tsedroen J. (eds.), Dignity and Discipline: Reviving Full Ordination for Buddhist Nuns (Boston: 2010); Lekshe Tsomo K. (ed.), Buddhist Women and Social Justice (Albany: 2004).

24 See Willis J., "Nuns and Benefactresses: The Role of Women and Philosophic Innovation in the Development of Buddhism." In Haddad Y. - Findly E. (eds.), Women, Religion, and Social Change (Albany: 1985). 
a route that some women embraced in a more radical way to take refuge from worldly concerns - especially the destiny of being a pawn in wider marriage strategies - and aspire to spiritual liberation. In doing so they were relying on what Alan Sponberg defined as 'soteriological inclusiveness,', ${ }^{25}$ which contrasted with more misogynous and androcentric attitudes in Buddhism. It is not surprising that Chokyi Dronma (and her reincarnations) became the protectress of women who refuse marriage. ${ }^{26}$ The biography of Chokyi Dronma shows that women's participation in religious life, both in domestic and public settings, was significant, albeit often neglected. She emerges from the narrative as part of a wider spiritual network that connected lay and monastic worlds, within which women played an important albeit unrecognized part. In some ways she recalls the Renaissance women who asserted themselves in a maledominated religious and political world, often experiencing challenging lives and contributing to great achievements.

\section{Bibliography}

\section{Archival Sources}

Biography of Bo dong Phyogs las rnam rgyal I = Amoghasiddhi 'Jigs med 'bangs, Bo dong pan chen gyi rnam thar. 1990. Lhasa: Bod ljongs bod yig dpe rnying dpe skrun khang.

Biography of Chos kyi sgron ma = Ye shes mkha' 'gro bsod nams'dren gyi sku skyes gsum pa rje btsun ma chos kyi sgron ma'i rnam thar. 144 folios. Incomplete manuscript.

Biography of Kun tu bzang mo = Dus gsum rgyal ba ma lus pa bskyed pa'i yum chen kun tu bzang mo'i rnam par thar pa zab don gter mdzod mthong ba don ldan by mKhyan rab dbang phyug, manuscript of 73 folios, 1551 .

Biography of Thang stong rgyal po = 'Gyur med bde chen, Thang rgyal rnam thar. 1982. Chengdu: Si khron mi rigs dpe skrun khang.

Bo dong chos 'byung = Chi med 'od zer, $d$ Pal de kho na nyid 'dus pa las bo dong chos byung gsal byed sgron me, Manuscript of 35 folios, kept at Bo dong E monastery of Tibet.

25 Discussing early Buddhist sources Alan Sponberg highlights their inconsistency in relationship to gender, which he describes as 'multivocality'. 'Soteriological inclusiveness' can be found alongside 'institutional androcentrism', 'ascetic mysoginism' and 'soteriological androgyny' . See Sponberg A., "Attitudes Towards Women and the Feminine in Early Buddhism." In Cabezon J.I. (ed.), Buddhism, Sexuality and Gender (Delhi: 1992) 3-36.

26 See Dhondup K. - Tsering T., "Samdhing Dorjee Phagmo:Tibet's only Female Reincarnation Line", Tibetan Review (1979) (August): 11-17. 


\section{Literature}

Bartoli M., Saint Clare: Beyond the Legend (Los Angeles: 2010).

Bynum C., Holy Fasts and Holy Feasts: The Religious Significance of Food to Medieval Women (Berkeley - London: 1992).

Dhondup K. - Tsering T., "Samdhing Dorjee Phagmo:Tibet's only Female Reincarnation Line", Tibetan Review 14 (1979) 11-17.

Davis N.Z., Women on the Margins: Three Seventeenth-Century Lives (Cambridge, Mass.: 1997).

Diemberger H., When a Woman Becomes a Dynasty: The Samding Dorje Phagmo of Tibet (New York: 2007).

Diemberger H., "Tibetan Women as Patrons of Printing and Innovation", in Diemberger H. - Ehrhard F.-K. - Kornicki P. (eds.), Tibetan Printing: Comparisons, Continuities and Change (Leiden: 2016) 267-308.

English E., Vajrayoginī: Her Visualizations, Rituals and Forms (Boston: 2002).

Everding K.H., Das Koenigreich Mang yul Gung thang, vols. 1 and 2 (Bonn: 200o).

Everding K.H., - Dzongphugpa D.D., Das tibetische Fürstentum La stod lHo (um 12651642). Die Geschichte der Herrschaftsbildung nebst einer Edition der Chronik Shel dkar chos 'byung (Wiesbaden: 2006).

Gyatso J. - Havnevik H. (eds.), Women in Tibet (New York: 2005).

Jacoby S., Love and Liberation: Autobiographical Writings of the Tibetan Buddhist Visionary Sera Khandro (New York: 2014).

Lekshe Tsomo K. (ed.), Buddhist Women and Social Justice (Albany: 2004).

Mohr T. - Tsedroen J. (eds.), Dignity and Discipline: Reviving Full Ordination for Buddhist Nuns (Boston: 2010).

de Nebesky-Wojkowitz, R., Oracles and Demons of Tibet: The Cult and Iconography of the Tibetan Protective Deities (The Hague: 1956).

Obeyesekere G., Medusa's Hair (Chicago: 1981).

Schaeffer K.R., Himalayan Hermitess: The Life of a Tibetan Buddhist Nun (Oxford - New York: 2004).

Sponberg A., "Attitudes Towards Women and the Feminine in Early Buddhism", in Cabezon I. (ed.), Buddhism, Sexuality and Gender (New York: 1992).

Tambiah S.J., The Buddhist Saints of the Forest and the Cult of Amulets: A Study in Charisma, Hagiography, Sectarianism, and Millennial Buddhism (Cambridge: 1984).

Wangdu, P. - Diemberger H., Shel dkar chos 'byung, History of the White Crystal (Vienna: 1996).

Willis J., "Nuns and Benefactresses: The Role of Women and Philosophic Innovation in the Development of Buddhism", in Haddad Y. - Findly E. (eds.), Women, Religion, and Social Change (Albany: 1985). 